\title{
Neurofilament-M Interacts with the $D_{1}$ Dopamine Receptor to Regulate Cell Surface Expression and Desensitization
}

\author{
Ok-Jin Kim, ${ }^{1}$ Marjorie A. Ariano, ${ }^{2}$ Robert A. Lazzarini, ${ }^{3}$ Michael S. Levine, ${ }^{4}$ and David R. Sibley ${ }^{1}$ \\ ${ }^{1}$ Molecular Neuropharmacology Section, National Institute of Neurological Disorders and Stroke, National Institutes of \\ Health, Bethesda, Maryland 20892-1406, 2Department of Neuroscience, The Chicago Medical School, North Chicago, \\ Illinois 60064, ${ }^{3}$ Department of Biochemistry and Molecular Biology, Mount Sinai School of Medicine, New York, New York \\ 10029, and ${ }^{4}$ Mental Retardation Research Center, University of California, Los Angeles, California 90095
}

\begin{abstract}
We used the yeast two-hybrid assay to identify novel proteins that interact with the $D_{1}$ dopamine receptor. The third cytoplasmic loop (residues 217-273) of the rat $D_{1}$ receptor was used as bait to identify clones encoding interacting proteins from a rat brain cDNA library. This identified two clones encoding the $\mathrm{C}$ terminus of rat neurofilament-M (NF-M) (residues 782-846). The NF-M clone did not interact with the third cytoplasmic loops of the rat $D_{2}, D_{3}$, or $D_{4}$ receptors, but showed weak interaction with that of the $D_{5}$ receptor. Coexpression of full-length NF-M with the $D_{1}$ receptor in HEK-293 cells resulted in $>50 \%$ reduction of receptor binding accompanied by a reduction in $D_{1}$ receptor-mediated CAMP accumulation. NF-M had no effect on the expression of other dopamine receptor subtypes. Using a $D_{1}$ receptor-green fluorescent protein chimera and confocal fluorescence microscopy, we found that NF-M reduced $D_{1}$ receptor expression at the cell surface and promoted accumu-
\end{abstract}

The molecular actions of dopamine are mediated by five distinct receptor subtypes, some of which exist in different protein isoforms attributable to alternative RNA splicing (Neve and Neve, 1997). These receptors belong to the G-protein-coupled receptor (GPCR) superfamily and are divided into two major subgroups, $\mathrm{D}_{1}$-like and $\mathrm{D}_{2}$-like, on the basis of their structure, pharmacology, and transductional properties (Neve and Neve, 1997). The $\mathrm{D}_{1}$-like subfamily is composed of the $\mathrm{D}_{1}$ and $\mathrm{D}_{5}$ subtypes, both of which transduce their signals by increasing intracellular cAMP levels. The $\mathrm{D}_{2}$-like subfamily consists of the $\mathrm{D}_{2}, \mathrm{D}_{3}$, and $\mathrm{D}_{4}$ receptors, all of which can diminish cAMP production and regulate calcium and potassium ion channels. Abnormal expression or regulation of dopaminergic receptors has been hypothesized to underlie neurological and endocrine disorders, including Parkinson's disease, schizophrenia, Tourette's syndrome, dystonia, essential hypertension, and hyperprolactinemia (Neve and Neve, 1997).

The regional expression and distribution of each dopamine receptor subtype in the CNS has been well described (McVittie et al., 1991; Huang et al., 1992; Levey et al., 1993; Ariano and Sibley,

\footnotetext{
Received Jan. 23, 2002; revised April 22, 2002; accepted April 29, 2002.

We thank Dr. H. Pant for providing the full-length NF-M cDNA, and Lindsey Christian and Ehud Gruen for technical assistance. This work was partially supported by Department of Defense Grant 17-99-1-9542 to M.A.A. and National Institutes of Health Grant NS33538 to M.S.L.

Correspondence should be addressed to Dr. David R. Sibley, Molecular Neuropharmacology Section, National Institute of Neurological Disorders and Stroke/ National Institutes of Health, Building 10, Room 5C108, 10 Center Drive, MSC 1406, Bethesda, MD 20892-1406. E-mail: sibley@helix.nih.gov.

Copyright (C) 2002 Society for Neuroscience $0270-6474 / 02 / 225920-11 \$ 15.00 / 0$
}

lation of the receptor in the cytosol. Interestingly, the $D_{1}$ receptors that were expressed at the cell surface in the presence of NF-M were resistant to agonist-induced desensitization. Cellular colocalization of NF-M and the $D_{1}$ receptor in the rat brain was examined by epifluorescence microscopy. These experiments showed that $\sim 50 \%$ of medium-sized striatal neurons expressed both proteins. Colocalization was also observed in pyramidal cells and interneurons within the frontal cortex. Similar immunohistochemical analyses using NF-M-deficient mice showed decrements in $D_{1}$ receptor expression compared with control mice. These results suggest that NF-M interacts with the $D_{1}$ receptor in vivo and may modify its expression and regulation.

Key words: $D_{1}$ receptor; neurofilament-M; yeast two-hybrid; interaction; desensitization; colocalization
1994; Smiley et al., 1994; Bergson et al., 1995; Ariano et al., 1997a,b; Muly et al., 1998). Overall, the $\mathrm{D}_{1}$ receptor is the most abundant and widely distributed subtype, followed closely by the $D_{2}$ receptor. The $D_{3}, D_{4}$, and $D_{5}$ receptors are not as widely distributed and are expressed at lower levels than the predominant $\mathrm{D}_{1}$ and $\mathrm{D}_{2}$ subtypes. Recent investigations have indicated that many of the dopamine receptor subtypes exhibit discrete subcellular localizations. For instance, within cortical pyramidal cells, the $\mathrm{D}_{1}$ receptor is expressed predominantly in dendritic spines, whereas the $\mathrm{D}_{5}$ receptor is found primarily in dendritic shafts (Smiley et al., 1994; Bergson et al., 1995). Similarly, striatal $\mathrm{D}_{2}$ receptors are more concentrated in spiny dendrites and spine heads than in the somata of the medium spiny neurons (Levey et al., 1993). Both the $D_{1}$ and $D_{2}$ receptors have also been localized within axonal terminals, although typically not within the same projection pathway (Huang et al., 1992; Levey et al., 1993; Smiley et al., 1994). The mechanisms involved in transport, sorting, and targeting dopamine receptor subtypes to these discrete subcellular locations are entirely unknown.

Recent studies have begun to elucidate mechanisms for neurotransmitter receptor trafficking, membrane insertion, and anchoring, particularly for ligand-gated ion channels. Various proteins have been identified that may play a role in the aggregation and immobilization of glutamate receptors, including a family of PDZ domain-containing proteins that are involved in the synaptic localization of NMDA receptors (O'Brien et al., 1998; Kim and Huganir, 1999). Similarly, AMPA receptors are associated with proteins such as GRIP and PICK1 that may direct their sorting 
and synaptic expression (Dong et al., 1999; Kim and Huganir, 1999; Xia et al., 1999). The majority of these proteins have been identified through protein-protein interaction screens such as the yeast two-hybrid assay. We, and others, have begun to screen for dopamine receptor interacting proteins that may direct the transport, subcellular distribution, and anchoring of these receptor subtypes. Here we report that neurofilament-M (NF-M) is an interacting protein for the $\mathrm{D}_{1}$ dopamine receptor. The interaction of this neuronal cytoskeletal protein with the $\mathrm{D}_{1}$ receptor appears to regulate its cell surface expression and its ability to be desensitized by agonists.

\section{MATERIALS AND METHODS}

Plasmid construction and cDNA library screening. The yeast strain EGY48 was purchased from Display Systems Biotech (Vista, CA). The third cytoplasmic domain of the rat $\mathrm{D}_{1}$ dopamine receptor (amino acids $\mathrm{Ile}^{217}-\mathrm{Thr}^{273}$ ) was amplified by PCR using the sense primer $5^{\prime}$ GTATCTACAGGATTGCCCAGAAGC-3' containing a Bam 1 1 site and the antisense primer 5'-GCGTCTTTAGAACTTTCGTCTCCC-3' containing an XhoI site. This amplified PCR product was subcloned in-frame into the Bam $\mathrm{H} 1$ and $X h o I$ sites of the yeast expression vector pEG202, resulting in plasmid pEG202- ${ }_{1}{ }^{3 r d}$ encoding the LexA-D ${ }_{1}^{3 r d}$ fusion protein. The third cytoplasmic domains of the $\mathrm{D}_{2 \mathrm{~L}}, \mathrm{D}_{3}, \mathrm{D}_{4}$, and $\mathrm{D}_{5}$ dopamine receptors were amplified by PCR using the sense primers 5'-TCAAAATCTACATCGTCCTCCGGAAG-3', 5'-CCAGGATCT ACATAGTCCTGAGG-CAAA-3', 5'-TGGGCCACTTTCCGTGGCT TGCGGCG-3', and 5'-GTATCTACCGCAT-TGCGCAGGTGCAG-3', respectively, all containing a $B a m \mathrm{H} 1$ site, and the antisense primers 5'-GACTCACCGAAAGAAGAGGAAGACGAC-3',5'-CTGGGTGGCCTTC-TTCTCTCGAAGTGG-3'， 5'-CTCATCGCCTTGCG-CTCCCTTCCAGTG-3', and 5'-TTTGAAGACCTTGGTCTCCTTCTTGAT3', respectively, all containing an XhoI site. The individual PCR products were subcloned in-frame into the Bam H1 and $X h o I$ sites of the yeast expression vector pEG202 encoding the LexA fusion protein. The yeast expression vectors containing the $\mathrm{N}$ terminal half and the $\mathrm{C}$ terminal of the third cytoplasmic domain of the $\mathrm{D}_{5}$ receptor were generated using the sense primers 5'-GTATCTACCGCATTGCGCAGGTGCAG-3' and 5'CGGAGTCGTGGAGCCTATGAA-3', respectively, containing a BamH1 site, and the antisense primers 5'-GCAACTCTGAGCATGCTCAGC-3' and 5'-TTTGAAGACCTTGGTCTCCTTCTTGAT-3', respectively, containing an $X$ hoI site. A rat whole-brain cDNA library, subcloned into pJG4.5, was purchased from Origene Technologies (Rockville, MD). Two hybrid techniques (DupLex-A system) were performed as described (user's manual from Origene Technologies). For screening the cDNA library, the bait vector pEG202- ${ }_{1}^{3 r d}$ was transformed into yeast strain EGY48 using a lithium acetate protocol after transforming EGY48 with a LacZ reporter plasmid, pSH18-34. Transformation of EGY48 with both LacZ reporter plasmid and the bait plasmid confirmed that there was no interaction between LexA- $\mathrm{D}_{1}{ }^{3 r d}$ and reporter operator for inducing the expression of LacZ indicating no blue color on X-gal media lacking histidine and uracil. Also, there was no induction of leucine in EGY48 with bait plasmid showing no growth on media lacking histidine, uracil, and leucine. The EGY48 strains harboring the reporter plasmids and the bait plasmids were transformed with the rat cDNA brain library, and the transformants expressing the bait and interacting prey proteins were selected on medium lacking histidine, uracil, and tryptophan. The positive clones (His+, Ura +, Trp + ) were selected for further characterization. Plasmids from the selected clones were isolated using the Yeast DNA isolation system (Bio101, Inc., Vista, CA) and amplified in Escherichia coli. DNA sequencing was performed by the National Institute of Neurological Disorders and Stroke sequencing facility using automated methods.

In vitro binding assays. To generate a fusion protein encoding the $\mathrm{D}_{1}$ third cytoplasmic domain (amino acids 217-273) and poly-histidine, the $\mathrm{D}_{1}$ third cytoplasmic domain fragment (BamH1-XhoI) was subcloned into plasmid pQE32 digested with restriction endonucleases Bam $\mathrm{H} 1$ and SalI. This plasmid was then transformed into XL1blue bacteria. Bacterial fusion protein production was induced by addition of $1 \mathrm{~mm}$ isopropyl-1thio- $\beta$-D-galactopyranoside for $4 \mathrm{hr}$ at $37^{\circ} \mathrm{C}$. Insoluble fusion proteins were purified using $\mathrm{Ni}^{2+}$-nitrilotriacetic acid-Agarose. The cDNA encoding NF-M (amino acids 782-846) was excised from clone pJG4.5.clone N3 as an EcoR1 fragment and subcloned into pGEX5X1. This plasmid, pGEX5X1.NF-M (782-846), was transformed into E. coli strain BL21 gold, allowing the expression of NF-M as a glutathione $S$-transferase (GST) fusion protein. Bacterial fusion protein production was induced by addition of $1 \mathrm{~mm}$ isopropyl-1-thio- $\beta$-D-galactopyranoside for $4 \mathrm{hr}$ at $37^{\circ} \mathrm{C}$. Insoluble fusion protein was purified using glutathioneAgarose. His-tagged fusion proteins were immobilized with $\mathrm{Ni}^{2+}$. nitrilotriacetic acid-Agarose overnight at $4^{\circ} \mathrm{C}$ in binding buffer $(50 \mathrm{~mm}$ sodium phosphate, $\mathrm{pH} 7.4,10 \%$ glycerol, $0.05 \%$ Triton X-100 with protease inhibitor mixture), and non-bound proteins were removed by washing with binding buffer four times. GST-fusion protein or GST protein alone was incubated with the immobilized His-tagged $\mathrm{D}_{1}{ }^{3 \mathrm{rd}}$ in $400 \mu \mathrm{l}$ of binding buffer for $2 \mathrm{hr}$ at $4^{\circ} \mathrm{C}$. Proteins bound to the immobilized resin were collected by centrifugation, washed two times with 500 $\mathrm{mM} \mathrm{NaCl}$ in binding buffer and two times with binding buffer, eluted in $2 \times$ SDS sample buffer, and separated by SDS-PAGE (14\% acrylamide gel). Proteins were transferred to polyvinylidene difluoride (PVDF) membranes using semidry transblotter. PVDF membrane was incubated with anti-GST mouse monoclonal antibody $(0.1 \mu \mathrm{g} / \mathrm{ml})$ as primary antibody for $1 \mathrm{hr}$ at room temperature and washed four times with TBST (100 mm Tris, $\mathrm{pH} 7.4,150 \mathrm{~mm} \mathrm{NaCl}, 0.1 \%$ Tween 20 ) before incubating with secondary antibody, anti-mouse antibody conjugated with horseradish peroxidase $(1: 10,000)$, for $30 \mathrm{~min}$ at room temperature. Membranes were washed four times with TBST and developed using Super signal west pico chemiluminescent substrate (Pierce, Rockford, IL).

Cell culture and transfections. Human embryonic kidney (HEK)-293tsa201 cells were cultured in DMEM supplemented with $10 \%$ fetal calf serum, $1 \mathrm{~mm}$ sodium pyruvate, $50 \mathrm{U} / \mathrm{ml}$ penicillin, $50 \mu \mathrm{g} / \mathrm{ml}$ streptomycin, and $10 \mu \mathrm{g} / \mathrm{ml}$ gentamycin. Cells were grown at $37^{\circ} \mathrm{C}$ in $5 \% \mathrm{CO}_{2}$ and $90 \%$ humidity. The full-length rat $\mathrm{D}_{1}$ receptor expression plasmid was transfected with or without the rat full-length NF-M expression plasmid (gift from Dr. H. Pant, National Institute of Neurological Disorders and Stroke/National Institutes of Health) into HEK-293-tsa201 cells using the calcium phosphate precipitation method (Invitrogen). Cells were seeded in 100 or $150 \mathrm{~mm}^{2}$ plates, and transfection was performed when cells were $\sim 50 \%$ confluent. DNA and $60 \mu \mathrm{l}$ (30 $\mu \mathrm{l}$ for radioligand binding assays alone) of $2 \mathrm{M} \mathrm{CaCl}_{2}$ were mixed in $\mathrm{H}_{2} \mathrm{O}$ in a total volume of $1000 \mu \mathrm{l}$ and then slowly mixed with HEPES buffered saline (HBS). The reaction mixture was incubated at room temperature for $25 \mathrm{~min}$ and then evenly added to the cell culture dish containing $20 \mathrm{ml}$ of fresh media. After $18 \mathrm{hr}$, the transfection media was replaced with fresh media, and the cells were divided for radioligand and cAMP production assays. Cells were harvested the next day for the assays.

Radioligand binding assays. Cells were harvested by incubation with 5 mM EDTA in Earle's balanced salt solution (EBSS) and collected by centrifugation at $300 \times g$ for $10 \mathrm{~min}$. The cells were resuspended in lysis buffer (5 mM Tris, $\mathrm{pH} 7.4,5 \mathrm{~mm} \mathrm{MgCl}_{2}$, at $\left.4^{\circ} \mathrm{C}\right)$ and disrupted using a Dounce homogenizer followed by centrifugation at $35,000 \times g$ for 20 min. The resulting membrane pellet was resuspended in binding buffer (50 mM Tris, $\mathrm{pH}$ 7.4). The membrane suspension (final protein concentration $=20-30 \mu \mathrm{g}$ per tube) was then added to assay tubes containing $\left[{ }^{3} \mathrm{H}\right] \mathrm{SCH}-23390$ in a final volume of $1.0 \mathrm{ml}$. (+)-Butaclamol was added at the final concentration of $3 \mu \mathrm{M}$ to determine nonspecific binding. The assay tubes were incubated at room temperature for $1.5 \mathrm{hr}$, and the reaction was terminated by rapid filtration through $\mathrm{GF} / \mathrm{C}$ filters pretreated with $0.3 \%$ polyethyleneimine. Radioactivity bound to the filters was quantitated by liquid scintillation spectroscopy at a counting efficiency of $47 \%$.

Determination of cAMP production. Transfected HEK-293-tsa201 cells were seeded into 24 -well plates $(\sim 150,000$ cells per well $)$ and cultured for $1 \mathrm{~d}$ before the experiment. To assess desensitization, the cultures were first incubated in the absence or presence of dopamine with $0.2 \mathrm{~mm}$ sodium metabisulfite and $5 \mu \mathrm{M}(+/-)$-propranolol (to block endogenous $\beta$-adrenergic receptors) and in HDMEM (20 mM HEPES buffered DMEM, pH 7.4 at $37^{\circ} \mathrm{C}$ ). Subsequently, the cells were washed four times with $400 \mu \mathrm{l}$ of EBSS $\left(37^{\circ} \mathrm{C}\right)$ and further incubated with various concentrations of dopamine in a total volume of $250 \mu \mathrm{l}$ at $37^{\circ} \mathrm{C}$ for $15 \mathrm{~min}$ in the presence of $30 \mu \mathrm{M}$ Ro-20-1724, $0.2 \mathrm{~mm}$ sodium metabisulfite, and $5 \mu \mathrm{M}$ $(+/-)$-propranolol. The reaction was terminated by discarding the supernatant and adding $200 \mu \mathrm{l}$ of $3 \%$ perchloric acid per well. After incubating on ice for $30 \mathrm{~min}, 80 \mu \mathrm{l}$ of $15 \% \mathrm{KHCO}_{3}$ was added to the wells, and the plates were further incubated for $10 \mathrm{~min}$. The plates were then centrifuged for $10 \mathrm{~min}$ at $1300 \times \mathrm{g}$, and $50 \mu \mathrm{l}$ of the supernatant from each well was subsequently transferred to a $1.2 \mathrm{ml}$ tube containing $250 \mu \mathrm{l}$ of reaction mixture $(150 \mu \mathrm{l}$ of Tris-EDTA buffer, $50 \mu \mathrm{l}$ of cAMP binding protein, and $50 \mu \mathrm{l}$ of $\left.\left[{ }^{3} \mathrm{H}\right] \mathrm{cAMP}\right)$. After incubation at $4^{\circ} \mathrm{C}$ overnight, $250 \mu$ l of charcoal-dextran mix $(1 \%)$ was added to each tube followed by incubation at $4^{\circ} \mathrm{C}$ for $15 \mathrm{~min}$ and then centrifugation for 15 min at $1300 \times g$. Radioactivity in the supernatant from each tube was 
quantified by liquid scintillation spectroscopy at a counting efficiency of $47 \%$. cAMP concentrations were calculated using a standard curve according to the protocol of the assay kit.

Immunofluorescence histochemistry. Specific polyclonal antisera generated in rabbits against the $D_{1}$ and $D_{2}$ receptor subtypes have been characterized extensively (McVittie et al., 1991; Ariano and Sibley, 1994; Levine et al., 1996). A mouse monoclonal antibody against neurofilament-160 kDa (NF-M) was purchased from Zymed Laboratories (South San Francisco, CA). The NF-M-deficient mice have been described previously (Elder et al., 1998a,b). We used NF-M-deficient mice that had been back-crossed into the C57BL/6 strain for six generations and C57BL/6 wild-type mice for controls. Tissue sections were obtained from fresh, frozen rat or mouse brains and stained simultaneously for immunofluorescence histochemistry or singly for the $D_{2}$ receptor subtype. The antisera were diluted in PBS, $\mathrm{pH} 7.2$, applied together (dilutions: $\mathrm{D}_{1}, 1: 200$; NF-M, 1:100; $\mathrm{D}_{2}, 1: 200$ ) to the slidemounted, fresh-frozen sections and incubated overnight at $4^{\circ} \mathrm{C}$ in a humidified environment. The next day, unbound primary antisera were rinsed off, and secondary, fluorescently labeled antisera (donkey antirabbit or donkey anti-mouse, conjugated to either $\mathrm{Cy} 2$ or $\mathrm{Cy} 3$; Jackson ImmunoResearch, West Grove, PA) were diluted 1:200 in PBS and applied for $2 \mathrm{hr}$ at $4^{\circ} \mathrm{C}$ in a humidified environment. Additional experiments examined individual immunofluorescence detection of the $\mathrm{D}_{1}$ receptor or NF-M to validate that combined, simultaneous detection of the two proteins did not compromise the respective individual expression patterns. Controls included using multiple $\mathrm{D}_{1}$ receptor antisera, directed against different epitopes of the $\mathrm{D}_{1}$ receptor protein sequence, and omission of the primary antisera. No differences were noted between double- or single-label immunofluorescence incubations.

Fluorescence microscopy. Brain sections processed for immunohistochemistry were examined using standard epifluorescence microscopy (Olympus BX41). Digitized images of the experimental tissues in different brain areas were made with a megapixel camera (Optronics, Goleta, CA). Image acquisition parameters for each antisera staining experiment were optimized to use the entire grayscale range (0-255). At least four different experimental incubations were evaluated for the combined $\mathrm{D}_{1}$ and NF-M staining. The fluorescent staining reactions were stored and electronically merged using Adobe Photoshop off-line.

Confocal microscopy. HEK293 cells were cultured in DMEM supplemented with $10 \%$ fetal calf serum, $1 \mathrm{~mm}$ sodium pyruvate, $50 \mathrm{U} / \mathrm{ml}$ penicillin, $50 \mu \mathrm{g} / \mathrm{ml}$ streptomycin, and $10 \mu \mathrm{g} / \mathrm{ml}$ gentamycin. Cells were grown at $37^{\circ} \mathrm{C}$ in $5 \% \mathrm{CO}_{2}$ and $90 \%$ humidity. Cells were seeded on glass-bottom poly-D-lysine-coated $35 \mathrm{~mm}$ plates (MatTek Corporation, Ashland, MA) before the transfection with a $\mathrm{D}_{1}$ receptor tagged with GFP $\left(D_{1}\right.$-GFP $)$ or $D_{1}$-GFP and NF-M. Cells were washed with the fresh media the next day. Twenty-four to $36 \mathrm{hr}$ after transfection, cells were subjected to confocal fluorescence microscopy (LSM410).

Data analysis. Radioligand binding assays were routinely performed in triplicate and repeated three to nine times. cAMP experiments were performed in duplicate and repeated three to four times. Estimation of the radioligand binding parameters, $K_{\mathrm{D}}$ and $B_{\max }$, as well as the $\mathrm{EC}_{50}$ values for dopamine stimulation of cAMP production, were calculated using the GraphPad Prizm curve-fitting program.

\section{RESULTS}

\section{Interaction of NF-M with the third cytoplasmic loop of the $D_{1}$ dopamine receptor}

To identify proteins that interact with the $\mathrm{D}_{1}$ dopamine receptor, a yeast two-hybrid screen was performed using the third cytoplasmic loop (amino acids Ile ${ }^{217}-\mathrm{Thr}^{273}$ ) of the $\mathrm{D}_{1}$ receptor protein as bait (Fig. $1 A$ ). A total of $4 \times 10^{6}$ library transformants were screened, resulting in the identification of eight positive cDNA clones. These cDNAs were sequenced, and two identical clones encoding a C-terminal fragment of NF-M were selected for further study. NF-M is a midsized intermediate filament protein with well defined head, helical rod, and C-terminal tail domains (Fig. $1 B$ ). In neurofilaments, the $\mathrm{C}$-terminal tail domains are greatly extended, relative to other intermediate filaments, and contain glutamic acid-rich regions of unknown significance (Lee and Cleveland, 1996; Elder et al., 1998a,b). Both of the partiallength cDNAs encoded the last 65 residues of the NF-M C

\section{A}

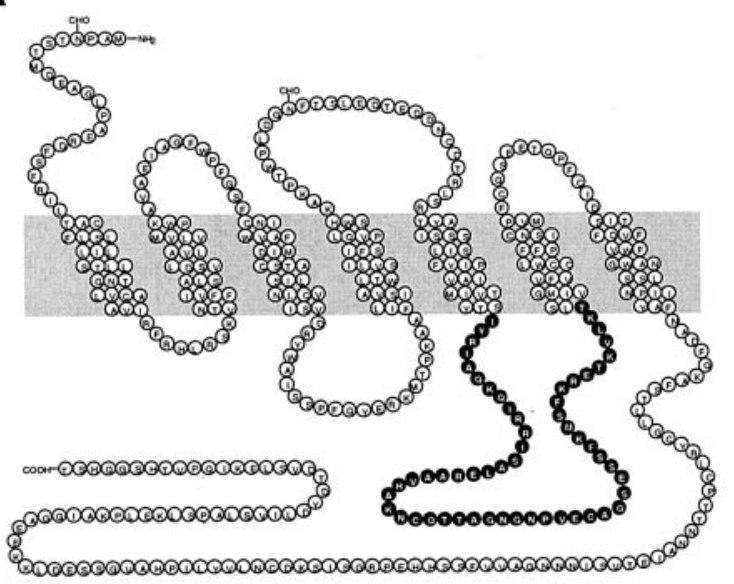

B

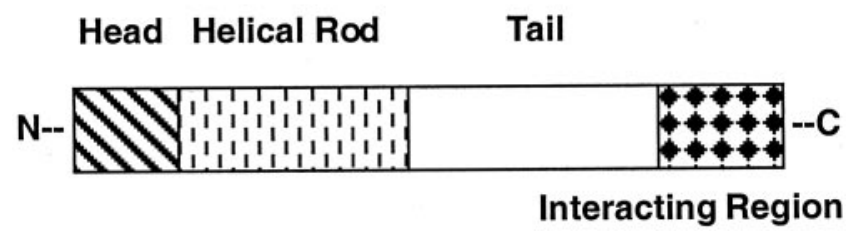

Figure 1. Diagrams of rat $\mathrm{D}_{1}$ dopamine receptor and NF-M proteins. $A$, Structure of the rat $\mathrm{D}_{1}$ dopamine receptor as it is believed to be organized in the plasma membrane. Solid circles represent the portion of the third cytoplasmic loop (amino acids Ile $217-\mathrm{Thr}^{273}$ ) that was used to construct the bait protein for the yeast two-hybrid screen. $B$, Diagram of the rat NF-M protein showing the head, helical rod, and tail regions of the 160 $\mathrm{kDa}$ protein. The region of the NF-M protein found to interact with the third cytoplasmic loop of the $\mathrm{D}_{1}$ receptor is indicated at the $\mathrm{C}$ end of the tail domain.

terminus (residues $782-846$ ) as well as $\sim 0.5 \mathrm{~kb}$ of $3^{\prime}$ untranslated sequence (Fig. $1 B)$.

To evaluate the specificity of the $\mathrm{D}_{1}$ receptor-NF-M interaction, we examined the interaction of the partial-length NF-M clone with the third cytoplasmic domains of all dopamine receptor subtypes (Table 1). No interaction was detected with any of the $\mathrm{D}_{2}$ subfamily of receptors, $\mathrm{D}_{2 \mathrm{~L}}, \mathrm{D}_{3}$, or $\mathrm{D}_{4}$; however, a very weak interaction was detected with the third cytoplasmic loop of the $\mathrm{D}_{5}$ receptor (Table 1 ). The $\mathrm{D}_{1}$ and $\mathrm{D}_{5}$ receptors show high sequence homology, especially within the putative transmembrane spanning domains (Fig. 2). The sequences are more divergent in intracellular domains; however, within the third cytoplasmic loops, the N-terminal regions show higher homologies compared with the C-terminal regions (Fig. 2). We thus decided to test which area of the third cytoplasmic loop of the $\mathrm{D}_{5}$ receptor weakly interacted with the NF-M clone. We prepared two bait plasmids, one consisting of the N-terminal area of the third cytoplasmic loop of the $\mathrm{D}_{5}$ receptor (residues $\mathrm{Ile}^{222}-\mathrm{Cys}^{245}$ ) and the other consisting of the C-terminal area of this loop (residues $\mathrm{Arg}^{246}-\mathrm{Thr}^{270}$ ) (Fig. 2). These bait plasmids were then evaluated using the yeast two-hybrid assay (Table 1). As shown, the $\mathrm{N}$-terminal region of the third cytoplasmic loop of the $\mathrm{D}_{5}$ receptor interacted with the NF-M clone; however, the C-terminal region did not. The interaction of the $\mathrm{D}_{5}$ receptor $\mathrm{N}$-terminal third loop fragment was not as strong, however, as the third cytoplasmic loop of the $\mathrm{D}_{1}$ receptor (Table 1). 
Table 1. Yeast two-hybrid interactions of the NF-M clone with the third cytoplasmic loops of all dopamine receptors

\begin{tabular}{lll} 
& Gal/Raf-H-U-W-L & Gal/Raf-H-U-W, X-Gal \\
DA receptors & NF-M & NF-M \\
\hline $\mathrm{D}_{1}$ & Yes & 3 \\
$\mathrm{D}_{2}$ & No & 0 \\
$\mathrm{D}_{3}$ & No & 0 \\
$\mathrm{D}_{4}$ & No & 0 \\
$\mathrm{D}_{5}$ & Yes & 1 \\
$\mathrm{D}_{5}-\mathrm{N}$ terminus & Yes & 2 \\
$\mathrm{D}_{5}-\mathrm{C}$ terminus & No & 0 \\
$\mathrm{D}_{1}$-N terminus & Yes & 2 \\
$\mathrm{D}_{1}-\mathrm{C}$ terminus & Yes & 2 \\
LexA & No & 0 \\
Positive control & Yes & 4 \\
\hline
\end{tabular}

$\overline{\text { Bait proteins were constructed, and yeast two-hybrid assays were performed as }}$ described in Materials and Methods. Bait proteins labeled " $\mathrm{N}$ terminus" and " $\mathrm{C}$ terminus" refer to the $\mathrm{N}$ - and $\mathrm{C}$-terminal portions of the third cytoplasmic loops of the $\mathrm{D}_{1}$ and $\mathrm{D}_{5}$ receptors. "Yes" refers to growth of yeast in media lacking histidine, uracil, tryptophan, and leucine (Gal/Raf-H-U-W-L). Numbers denote the relative intensity of "blue" color detected in media containing X-gal. Negative (LexA) and positive controls are shown. The positive control represents the yeast two-hybrid result using bait and prey plasmids expressing the P53 and LTA interacting proteins. This positive control provided the "bluest" color change and was arbitrarily assigned the number 4 .

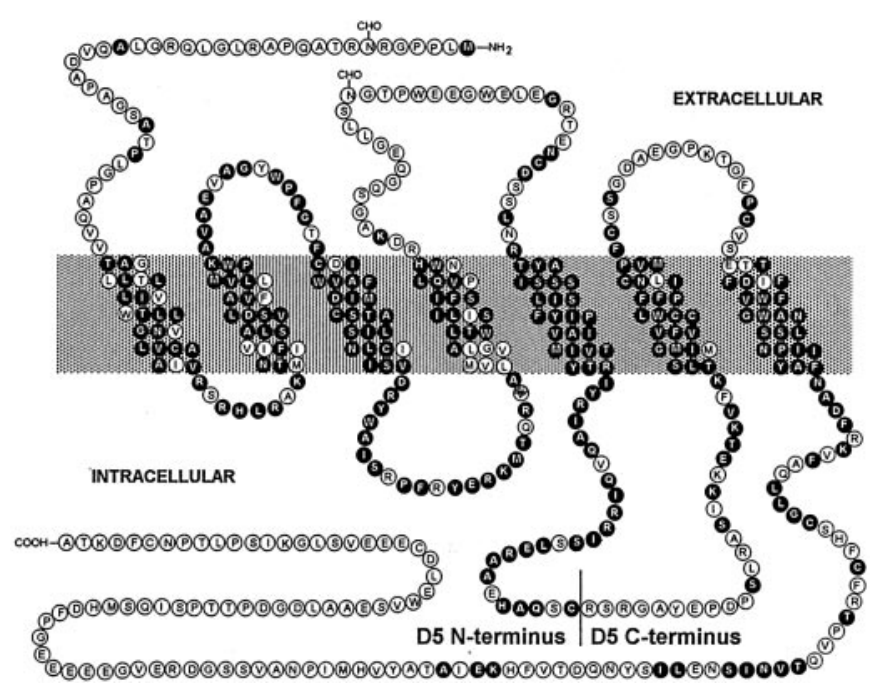

Figure 2. Structure of the rat $\mathrm{D}_{5}$ dopamine receptor. The black residues are identical between the $D_{1}$ and $D_{5}$ receptors. The line in the third cytoplasmic loop designates the end and the beginning of the $\mathrm{N}$-terminal and C-terminal bait proteins, respectively (see Results).

These results suggest that the corresponding area of the $\mathrm{D}_{1}$ receptor, the $\mathrm{N}$-terminal region of the third cytoplasmic loop, is part of the NF-M interaction domain. To test this further, we prepared corresponding bait proteins consisting of the N-terminal $\left(\mathrm{Ile}^{217}-\mathrm{Cys}^{241}\right)$ and C-terminal $\left(\mathrm{Gln}^{242}-\mathrm{Thr}^{273}\right)$ fragments of the third cytoplasmic loop of the $\mathrm{D}_{1}$ receptor and tested them using the two-hybrid assay (Table 1). Surprisingly, both of these fragments were positive with respect to interacting with NF-M; however, when tested individually, their interactions with NF-M were not as strong as that seen when the entire third cytoplasmic loop was used (Table 1). These results suggest that NF-M actually interacts with multiple residues throughout the entire third cytoplasmic loop.

The specificity of the interaction of the NF-M clone with the

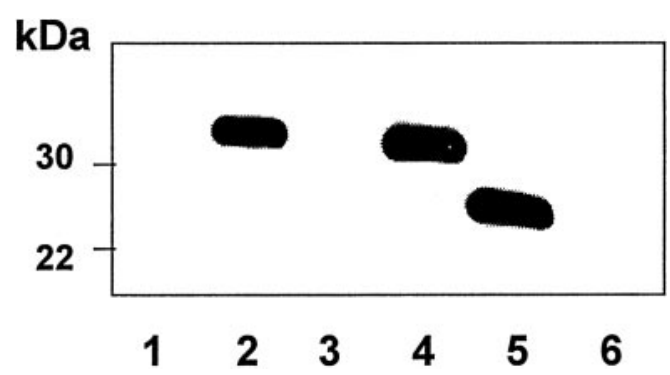

Figure 3. In vitro binding assay. Bacterial fusion proteins, $\mathrm{D}_{1}{ }^{3 \mathrm{rd}}-\mathrm{His}$ and NF-M-GST, were produced as described in Materials and Methods. $\mathrm{D}_{1}{ }^{3 \mathrm{rd}}$-His was immobilized with $\mathrm{Ni}^{2+}$-nitrilotriacetic acid-Agarose overnight at $4^{\circ} \mathrm{C}$ (Lane 1-3). NF-M-GST (lane 2) or GST alone (lane 3) was next incubated with the immobilized $\mathrm{D}_{1}{ }^{3 \mathrm{rd}}$-His protein for $2 \mathrm{hr}$ at $4^{\circ} \mathrm{C}$. Lane 6 shows NF-M-GST incubated with the gel in the absence of $\mathrm{D}_{1}{ }^{3 \mathrm{rd}}$-His. Non-bound proteins were removed by washing. Proteins remaining bound to the immobilized resin were collected by centrif ugation, washed, and eluted in SDS sample buffer. Lanes 4 and 5 show the NF-M-GST and GST proteins directly dissolved in SDS-PAGE sample buffer. Samples were subjected to SDS-PAGE and blotting as described in Materials and Methods. The experiment shown is representative of three such experiments.

third cytoplasmic loop of the $\mathrm{D}_{1}$ receptor was further confirmed using an in vitro binding assay (Fig. 3). For this experiment, we constructed a GST fusion protein with the NF-M clone and a polyhistidine-tagged construct of the third cytoplasmic loop of the $D_{1}$ receptor $\left(D_{1}{ }^{3 \text { rd }}-\mathrm{His}\right)$. Both of these proteins were expressed in bacteria and used for the in vitro binding assay. Figure 3 shows an SDS-PAGE gel blotted with antisera raised against the GST protein. Lanes 4 and 5 show the NF-M-GST fusion protein and GST alone, respectively. Lanes 1-3 show eluates from a

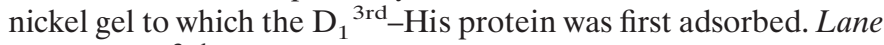
1 shows $\mathrm{D}_{1}{ }^{3 \mathrm{rd}}$-His alone, lane 2 shows co-adsorbtion with the NF-M-GST fusion protein followed by washing before elution, and lane 3 shows co-adsorbtion with GST alone. Lane 6 shows NF-M-GST adsorption to the nickel gel in the absence of the $\mathrm{D}_{1}{ }^{3 \mathrm{rd}}$-His protein. The NF-M-GST protein is retained on the gel only in the presence of the $\mathrm{D}_{1}{ }^{3 \mathrm{rd}}$-His protein (lane 2), thus demonstrating a direct interaction between these proteins.

\section{Effect of NF-M on $D_{1}$ receptor expression in HEK293 cells}

To investigate functional interactions between NF-M and the $\mathrm{D}_{1}$ receptor, we coexpressed the proteins and examined the effect on receptor expression levels. Figure $4 A$ shows the results of overexpressing the full-length rat NF-M protein on the expression of the $\mathrm{D}_{1}$ receptor in HEK293 cells. In the presence of NF-M, the maximum binding capacity of the $\mathrm{D}_{1}$ receptor is reduced by $>50 \%$ in the HEK293 cell membranes. This appears to be an effect on the total receptor number in the membranes as opposed to a change in affinity for the radioligand (Fig. $4 A$ ). Because equal amounts of DNA were used in each transfection group, the decreased expression of the $\mathrm{D}_{1}$ receptor appears to be a direct result of NF-M expression rather than a decreased efficiency of transfection for the $\mathrm{D}_{1}$ receptor construct.

In contrast to the reduction in $\mathrm{D}_{1}$ receptor expression by NF-M, there was no effect of coexpressing full-length NF-M on the expression of the $\mathrm{D}_{2}$ subfamily of receptors, $\mathrm{D}_{2}, \mathrm{D}_{3}$, or $\mathrm{D}_{4}$ (data not shown). These results are consistent with the yeast two-hybrid results shown in Table 1 and demonstrate that the effects of NF-M on $D_{1}$ receptor expression are specific. Figure $4 B$ 

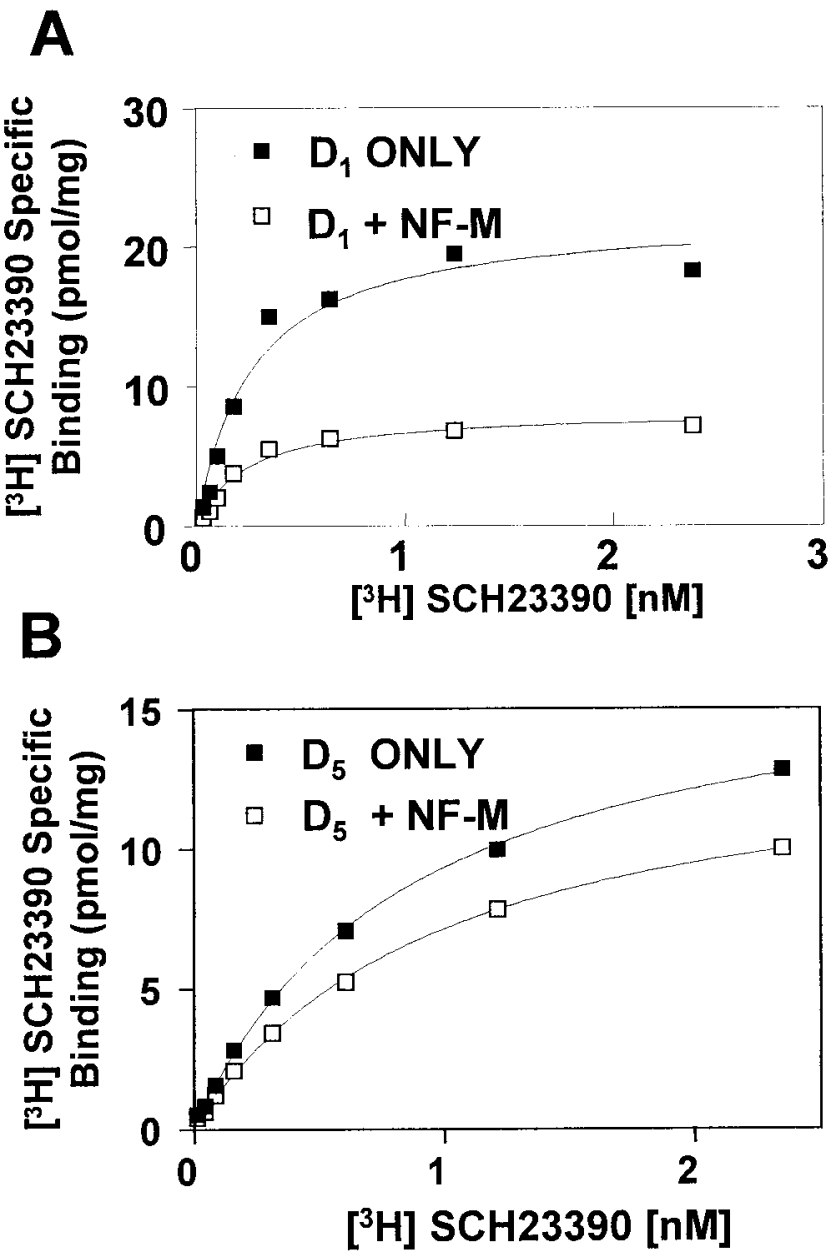

Figure 4. Effect of NF-M on $\mathrm{D}_{1}$ and $\mathrm{D}_{5}$ receptor expression. HEK293tsa201 cells were transfected as described in Materials and Methods either with just the receptor expression plasmids $\left(D_{1} / D_{5}\right.$ only $)$ or with an expression vector encoding the full-length rat NF-M protein $\left(D_{1} / D_{5}+N F-M\right)$. Equal amounts of receptor expression vectors were added, and an appropriate amount of empty expression vector was included in the $D_{1} / D_{5}$ only groups such that equal amounts of DNA would be used in each transfection. Saturation radioligand binding assays in cell membranes using the $\mathrm{D}_{1}$-like selective radiolabeled antagonist, $\left[{ }^{3} \mathrm{H}\right] \mathrm{SCH} 23390$, were performed as described in Materials and Methods. $A$, The experiment shown for the $D_{1}$ receptor is representative of three such experiments. The binding parameters of this experiment are as follows: $D_{1} O N L Y, K_{\mathrm{d}}=0.26$ $\mathrm{nM}, B_{\max }=22 \mathrm{pmol} / \mathrm{mg} ; D_{1}+N F-M, K_{\mathrm{d}}=0.24 \mathrm{nM}, B_{\max }=8.2 \mathrm{pmol} / \mathrm{mg}$. $B$, The experiment shown for the $\mathrm{D}_{5}$ receptor is representative of three such experiments. The binding parameters of this experiment are as follows: $D_{5} O N L Y, K_{\mathrm{d}}=0.89 \mathrm{nM}, B_{\max }=17 \mathrm{pmol} / \mathrm{mg} ; D_{5}+N F-M, K_{\mathrm{d}}=$ $0.99 \mathrm{nM}, B_{\max }=14 \mathrm{pmol} / \mathrm{mg}$.

shows the effects of coexpressing NF-M on the expression of the $\mathrm{D}_{5}$ receptor. In this case, the results were variable in that sometimes a small decrease in expression was observed, whereas in other experiments there was no effect. These observations are congruent, however, with the weak interaction that was observed with the partial-length NF-M clone and the third cytoplasmic loop of the $\mathrm{D}_{5}$ receptor assessed using the yeast two-hybrid assay (Table 1). Taken altogether, the results in Table 1 and Figure 4 indicate that NF-M specifically interacts with the $\mathrm{D}_{1}$ receptor and that one consequence of this interaction is to diminish receptor binding activity in HEK293 cells.

To further examine the effect of NF-M on $\mathrm{D}_{1}$ receptor expression, we used a $\mathrm{D}_{1}$ receptor construct in which the green fluores-
- NF-M

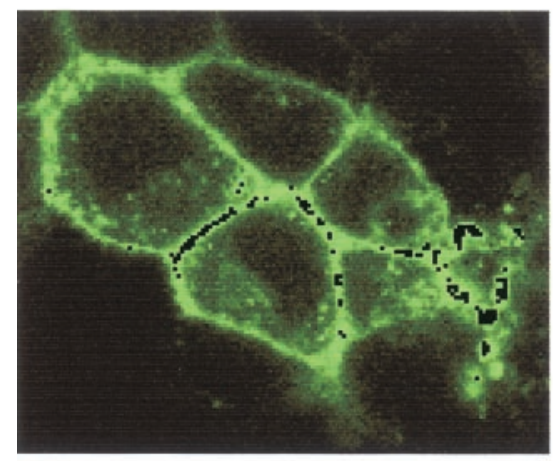

\section{+ NF-M}

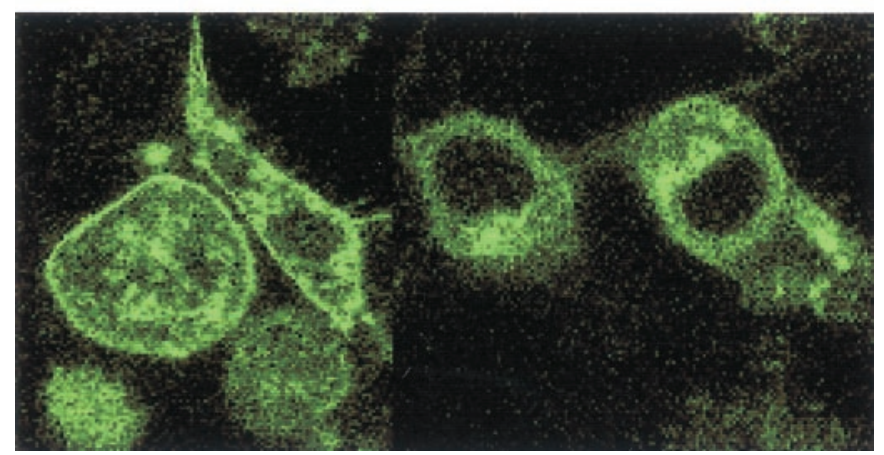

Figure 5. Expression of $\mathrm{D}_{1}$ receptor-GFP in HEK293 cells. The subcellular distribution of the $\mathrm{D}_{1}$ receptor-GFP in HEK293 cells was assessed using confocal fluorescence microscopy. The $\mathrm{D}_{1}$ receptor-GFP construct was transfected with or without NF-M as described in Figure 4 using HEK293-tsa201 cells seeded on the bottoms of poly-D-lysine-coated glass plates. Thirty-six hours subsequent to transfection, the medium was changed to DMEM supplemented with $25 \mathrm{mM}$ HEPES without phenol red before examining the cells using confocal fluorescence microscopy as described in Materials and Methods. Top panel shows $\mathrm{D}_{1}-\mathrm{GFP}$ receptor expression in the absence of NF-M, whereas the bottom panel shows expression in the presence of NF-M. An experiment representative of three is shown.

cent protein (GFP) was fused to the $\mathrm{C}$ terminus of the receptor. This enables us to visualize the subcellular location of the $D_{1}$ receptor using confocal fluorescence microscopy. Figure 5 shows the expression of the $\mathrm{D}_{1}$ receptor-GFP construct in HEK293 cells in the absence and presence of NF-M. In the absence of NF-M, the receptor is expressed predominantly in the plasma membrane at the cell surface with little internal fluorescence observed (Fig. 5, top panel). In contrast, in the presence of NF-M, a large fraction of the $D_{1}$ receptor appears to be located intracellularly, although some is still expressed at the cell surface (Fig. 5 , bottom panel). Addition of dopamine to the cotransfected cells had no effect on these results (data not shown). The data in Figure 5 may provide a morphological explanation for the experiment shown in Figure $4 A$, which primarily assessed $\mathrm{D}_{1}$ receptor binding in the plasma membrane. Coexpression of NF-M in HEK293 cells apparently reduces the cell surface expression of the $\mathrm{D}_{1}$ receptor and concomitantly increases its intracellular accumulation. 


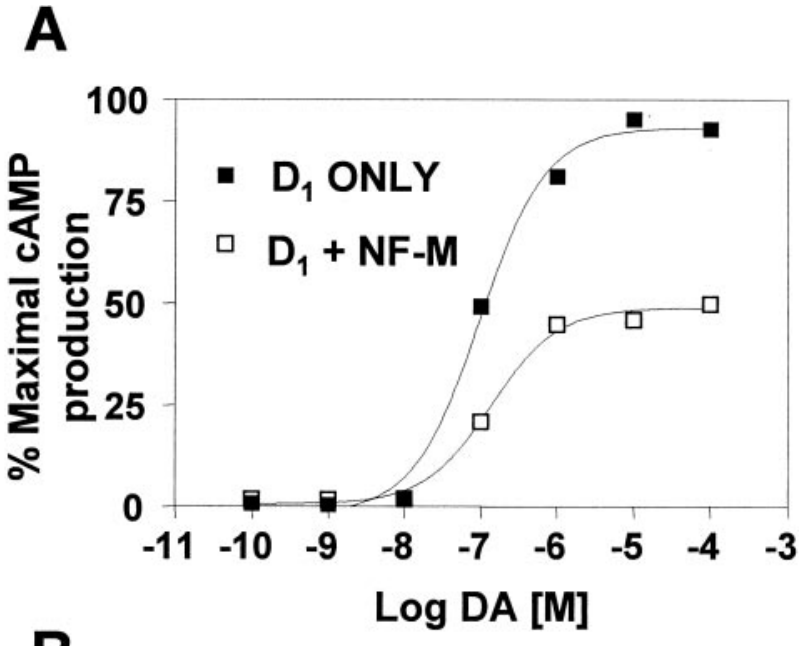

B

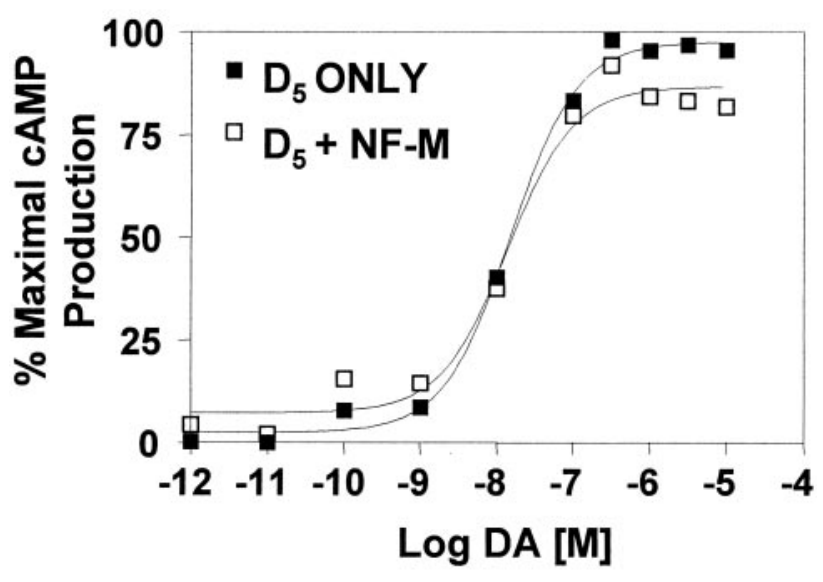

Figure 6. Effect of NF-M on $\mathrm{D}_{1}$ and $\mathrm{D}_{5}$ receptor-stimulated cAMP accumulation. HEK-293-tsa201 cells were transfected with equal amounts of the $\mathrm{D}_{1}$ or $\mathrm{D}_{5}$ receptor expression constructs and with either the NF-M expression construct or an appropriate amount of empty vector. One day subsequent to the transfection, the cells were used for cAMP generation as described in Materials and Methods. $A$, The closed squares indicate HEK293-tsa201 cells transfected with the $\mathrm{D}_{1}$ receptor alone, whereas the open squares indicate cotransfection with the $\mathrm{D}_{1}$ receptor and NF-M. The data are expressed as a percentage of the maximal response in the absence of NF-M. An experiment representative of three is shown. In the experiment shown, the following $\mathrm{EC}_{50}$ values were calculated: $D_{1} O N L Y, \mathrm{EC}_{50}=0.10 \mu \mathrm{M} ; D_{1}+N F-M$, $\mathrm{EC}_{50}=0.13 \mu \mathrm{M} . B$, The closed squares indicate HEK293-tsa201 cells transfected with the $\mathrm{D}_{5}$ receptor alone, whereas the open squares indicate cotransfection with the $\mathrm{D}_{5}$ receptor and NF-M. The data are expressed as a percentage of the maximal response in the absence of NF-M. An experiment representative of three is shown. In the experiment shown, the following $\mathrm{EC}_{50}$ values were calculated: $D_{5} O N L Y$, $\mathrm{EC}_{50}=15 \mathrm{nM} ; D_{5}+N F-M, \mathrm{EC}_{50}=14 \mathrm{~nm}$.

\section{Effect of NF-M on $D_{1}$ receptor function in HEK293 cells}

We next examined the ability of the receptor to increase intracellular cAMP accumulation when stimulated by agonists to further investigate functional interactions between NF-M and the $\mathrm{D}_{1}$ receptor. Figure $6 A$ shows the effect of coexpressing the full-length NF-M protein on $D_{1}$ receptor activation of adenylyl cyclase and cAMP accumulation in the HEK293 cells. In the absence of NF-M, dopamine stimulation of the $\mathrm{D}_{1}$ receptor produces a robust and potent accumulation of cAMP in the HEK293 cells (Fig. 6A). In the presence of NF-M, the maximum

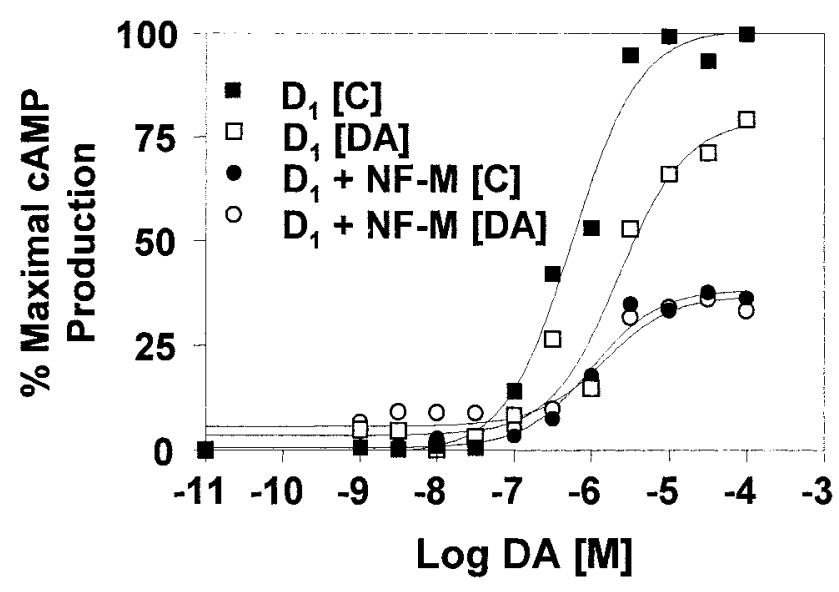

Figure 7. Effect of NF-M on agonist-induced desensitization of the $\mathrm{D}_{1}$ receptor. HEK-293-tsa201 cells were transfected with equal amounts of the $\mathrm{D}_{1}$ receptor expression construct and with either the NF-M expression construct or an appropriate amount of empty vector as described in Figure 4. The cells were washed with EBSS and then incubated in media alone (controls) or in the presence of $10 \mu \mathrm{M}$ dopamine for $30 \mathrm{~min}$ to induce desensitization as described in Materials and Methods. The cells were subsequently washed with EBSS and processed for the cAMP assays as described in Figure 6. The data are expressed as a percentage of the maximal response of the control group in the absence of NF-M. Closed squares represent $\mathrm{D}_{1}$ receptor transfection only, without dopamine pretreatment; open squares represent the same transfection group with the dopamine pretreatment. Closed circles represent $\mathrm{D}_{1}$ receptor and NF-M cotransfection without dopamine pretreatment; open circles represent the same transfection group with the dopamine pretreatment. This representative experiment was performed three times with similar results.

response to dopamine is decreased by $\sim 50 \%$; however, the potency for dopamine is unaffected (Fig. 6A). Interestingly, the magnitude of the effect of NF-M on decreasing maximal receptor-mediated cAMP accumulation is similar to that of decreasing the expression of the receptor on the cell surface (Fig. $4 A$ ). This may suggest that the decreased cAMP response is caused directly by the decreased receptor expression in the plasma membrane.

We also examined the effect of NF-M expression on the cAMP accumulation induced with the $\mathrm{D}_{5}$ receptor. Figure $6 B$ shows that overexpression of NF-M in the presence of the $D_{5}$ receptor produces minimal effects on receptor-stimulated cAMP accumulation in the HEK293 cells. These results are consistent with those shown in Figure $4 B$ for $D_{5}$ receptor expression and further suggest that NF-M interacts minimally, if at all, with the $D_{5}$ receptor in intact cells.

As a further approach to evaluate functional modification of $\mathrm{D}_{1}$ receptor activity by NF-M, we examined agonist-induced desensitization in the HEK293 cells. As with most G-proteincoupled receptors, the $\mathrm{D}_{1}$ receptor undergoes functional desensitization when activated with agonists (for review, see Sibley and Neve, 1997). This response appears to be mediated by receptor phosphorylation ( $\mathrm{Ng}$ et al., 1994; Tiberi et al., 1996; Gardner et al., 2001) followed by association with $\beta$-arrestin (Zhang et al., 1999 ) and is manifested by reduced cAMP generation in response to agonists. $\mathrm{D}_{1}$ receptor desensitization has been demonstrated previously using HEK293 cells (Tiberi et al., 1996). Figure 7 shows an experiment using HEK293 cells that were transfected with the $\mathrm{D}_{1}$ receptor alone or when coexpressed with NF-M. In the absence of NF-M, pretreatment of the cells with dopamine results in a diminished cAMP response when subsequently rechallenged with agonist (Fig. 7). In the presence of NF-M, there 

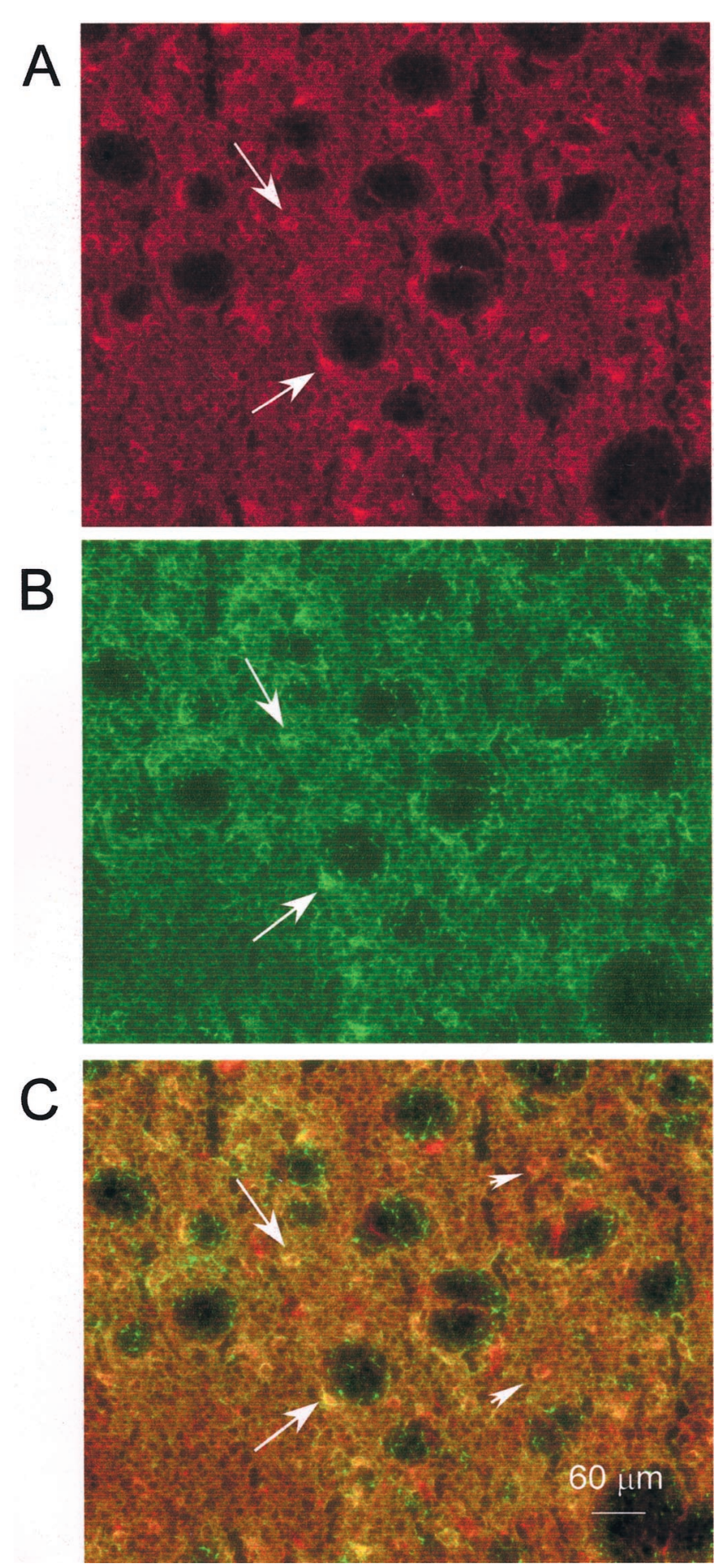

Figure 8. Coexpression of $\mathrm{D}_{1}$ receptor protein and NF-M in the rat striatum. Scale bar applies to all panels. $A, \mathrm{D}_{1}$ protein was detected using an antisera directed against the second extracellular loop of the receptor. Staining is visible within the thin cytoplasmic rim of medium-sized neurons (arrows) and within the neuropil as a red $(\mathrm{Cy} 3)$ reaction. Fiber bundles of the internal capsule do not show signal. $B$, NF-M was detected using a monoclonal antibody directed against a phosphate-independent epitope in the C-tail domain of the filament. The protein is expressed within neurons (arrows) and filaments throughout the striatum as bright green (Cy2) signals. Some axons coursing in the myelinated fibers within the internal capsule are seen. $C$, The $\mathrm{D}_{1}$ and NF-M images were merged electronically to demonstrate coexpression of the proteins. Coincidence is detected as a yellow signal in $>50 \%$ of the neurons (arrows) and also is a reduced response to dopamine under basal conditions, as observed in the experiment shown in Figure $6 A$. Surprisingly, in the presence of NF-M, pretreatment with dopamine had no further effect on $D_{1}$ receptor activity (Fig. 7). Thus, coexpression with NF-M in the HEK293 cells appears to abolish desensitization of the $\mathrm{D}_{1}$ receptor by agonists.

\section{Cellular coincidence of NF-M and the $D_{1}$ receptor in the brain}

We next assessed whether the interactions between NF-M and the $D_{1}$ receptor characterized in HEK293 cells might be meaningful in the brain. We hypothesized that coexpression of the two proteins must occur to consider NF-M as a viable dopamine receptor-interacting protein. Antisera directed toward the second extracellular loop of the rat $\mathrm{D}_{1}$ receptor and a monoclonal antibody directed against the $\mathrm{C}$-tail region of rat $\mathrm{NF}-\mathrm{M}$ were used to examine the cellular expression patterns of these proteins in various brain regions. The labeling for the $\mathrm{D}_{1}$ receptor subtype in the striatum was visible within a population of medium-sized neurons ( $\sim 20 \mu \mathrm{m}$ diameter) (Fig. 8A, arrows). Striatal neuropil, corresponding to dendritic processes, axon collaterals, and synaptic regions, also exhibited $\mathrm{D}_{1}$ receptor staining, as determined by the difference in fluorescent signal visible in this tissue compartment contrasted with the unstained myelinated fibers of passage in the internal capsule. This distribution is analogous to our previous findings (Ariano and Sibley, 1994; Levine et al., 1996). NF-M was expressed throughout the striatal neuropil, in cell bodies (Fig. $8 \mathrm{~B}$, arrows), and in some axons within the internal capsule. These images were merged electronically to demonstrate the overlap of the $\mathrm{Cy} 3$ and $\mathrm{Cy} 2$ signals used to detect the $\mathrm{D}_{1}$ receptor and NF-M, respectively, in Figure $8 \mathrm{C}$. Areas of coexpression are visible as yellow-stained cell bodies (arrows) and processes within the neuropil. Some striatal neurons expressed only $\mathrm{D}_{1}$ receptor (arrowheads) and appear as red-orange somata. We estimate that approximately half of the striatal neurons colocalize both proteins.

We also examined the distribution of the $\mathrm{D}_{1}$ receptor and NF-M within rostral areas of the cortex overlying the striatum (Fig. 9). A subgroup of layer 3 and layer 5 pyramidal neurons demonstrated colocalization of both proteins (arrows), especially evident within their somata. Subcellular areas of overlap of the $\mathrm{D}_{1}$ receptor and NF-M appear juxtaposed to the plasmalemma (Fig. $9 B$ ) and extend a short distance into the proximal portions of the apical and basilar dendrites of labeled pyramidal neurons. Single-labeled, $\mathrm{D}_{1}$ receptor-expressing pyramidal cells and interneurons are visible throughout the cortical laminations (arrowheads) and appear as red-orange somata. NF-M is localized prominently within the core of the apical dendrites of pyramidal neurons (Fig. 9A) and within a fine network of fibrils visible at higher magnification in the cortical neuropil (Fig. 9B).

\section{Dopamine receptor expression in NF-M-deficient mice}

To further evaluate the effect of NF-M on $\mathrm{D}_{1}$ receptor expression in the intact brain, we examined $\mathrm{D}_{1}$ receptor staining in the cortex and striatum of mice lacking NF-M. The NF-M-deficient mouse demonstrates diminished size in large and small diameter axons in the central and peripheral nervous systems (Elder et al.,

$\leftarrow$

throughout the neuropil. Some neurons only express the $\mathrm{D}_{1}$ receptor (arrowheads). This experiment was performed three times with similar results. 

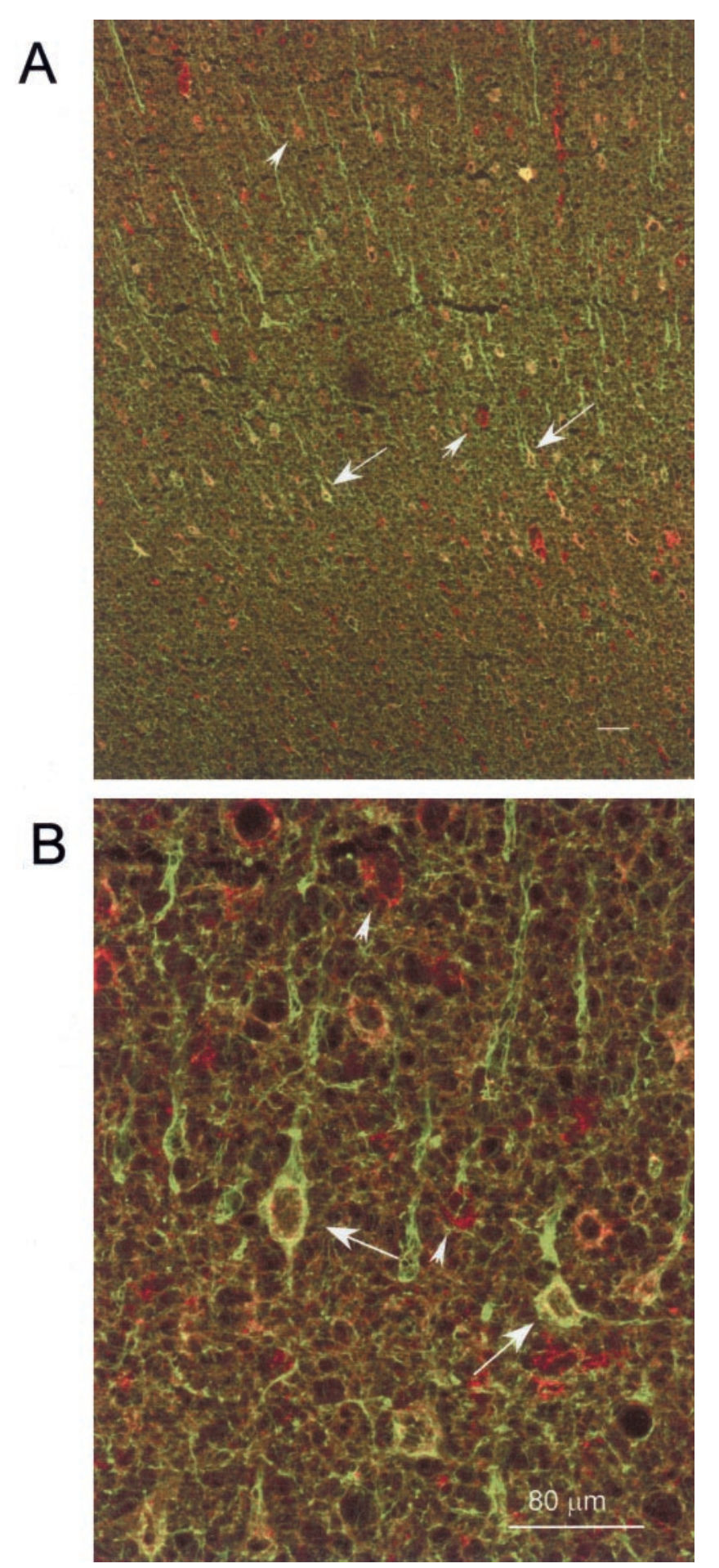

Figure 9. Coexpression of $\mathrm{D}_{1}$ receptor protein and NF-M in the rat somatosensory cortex. The pial surface is toward the top in each panel. $A$, Low-power image showing the coincident expression of the proteins as yellow signals (arrows) in the merged photomicrograph. Cell bodies expressing $\mathrm{D}_{1}$ receptor only (arrowheads) are visible throughout the cortical laminae as red-stained elements. NF-M is readily detected within the apical dendrites of pyramidal cells in the more superficial layers of the cortex as a green signal. $B$, Higher magnification of layer 5 of the rat cortex demonstrates the colocalization of the $\mathrm{D}_{1}$ receptor with NF-M in two pyramidal neurons (arrows). Single $\mathrm{D}_{1}$-positive labeled somata (arrowheads) are visible, as well as neuronal processes that are positive for NF-M alone. This experiment was performed three times with similar results.
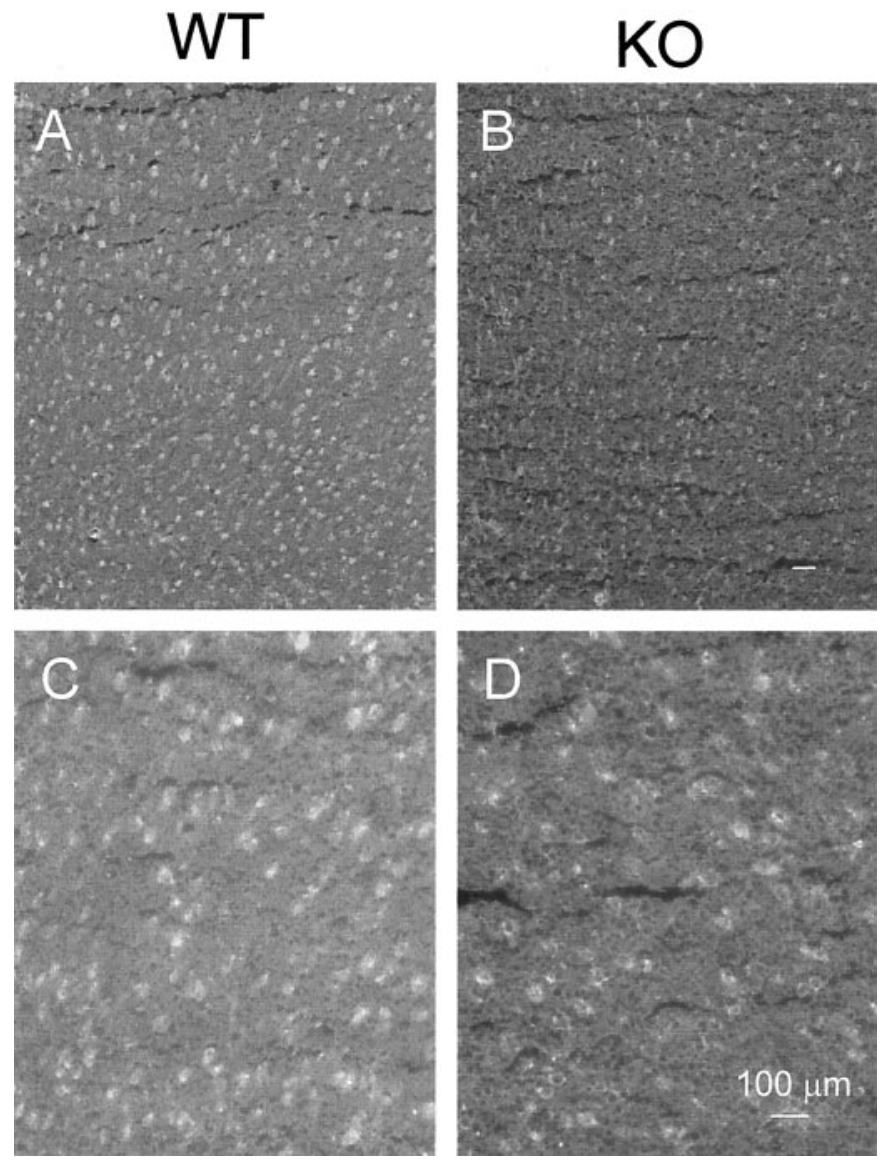

Figure 10. Cellular expression of the $\mathrm{D}_{1}$ receptor in wild-type or NFM-deficient mice is shown in the frontal cortex. The pial surface is toward the top edge of each image. Scale bar is the same for $A-D . A, \mathrm{D}_{1}$ receptor staining in the wild-type $(W T)$ is detected throughout the cortical laminas in somata and the neuropil. $B, \mathrm{D}_{1}$ receptor staining is reduced substantially throughout the NF-M knock-out $(K O)$ mouse cortex. $C, \mathrm{D}_{1}$ receptor staining is detected within pyramidal and nonpyramidal neuron populations, as well as in the cortical neuropil in the WT. D, $\mathrm{D}_{1}$ subtype staining is diminished in the $\mathrm{KO}$, and the pyramidal neurons lack a prominent apically oriented cell body. This experiment was performed in two sets of wild-type and knock-out animals with similar results.

1998a,b). We also noted attenuation in the thickness of the corpus callosum and a decrease in the diameter of the myelinated fiber bundles of the internal capsule in the NF-M-deficient mouse (data not shown). There was a noticeable decrement in the level of $\mathrm{D}_{1}$ receptor subtype staining within the cortex and striatum of the NF-M-deficient mouse, and this is demonstrated for the frontal cortex in Figure 10. The intensity of the fluorescent signal is decreased in the NF-M knock-out mouse compared with wild type, as shown in the lower-magnification images (Figs. 10 $A, B$ ) which span the cortical laminations from layer 2 at the top edge of the image to layer 6 at the bottom edge of the photomicrograph. In addition, there are fewer $D_{1}$ receptor-positive cells in the NF-M-deficient mouse. Cortical cell counts revealed that there were $47 \%$ fewer cells staining positive for the $D_{1}$ receptor in the NF-M-deficient mouse. Moreover, cortical pyramidal neurons in the NF-M-deficient mouse do not demonstrate proximal staining in the apical dendrites for the $\mathrm{D}_{1}$ receptor and seem to have less pronounced pyramidal cytoarchitecture (Fig. 10, compare $C, D$ ). As a control for these results, we examined the immunofluorescent distribution pattern of the $\mathrm{D}_{2}$ receptor, which we have 

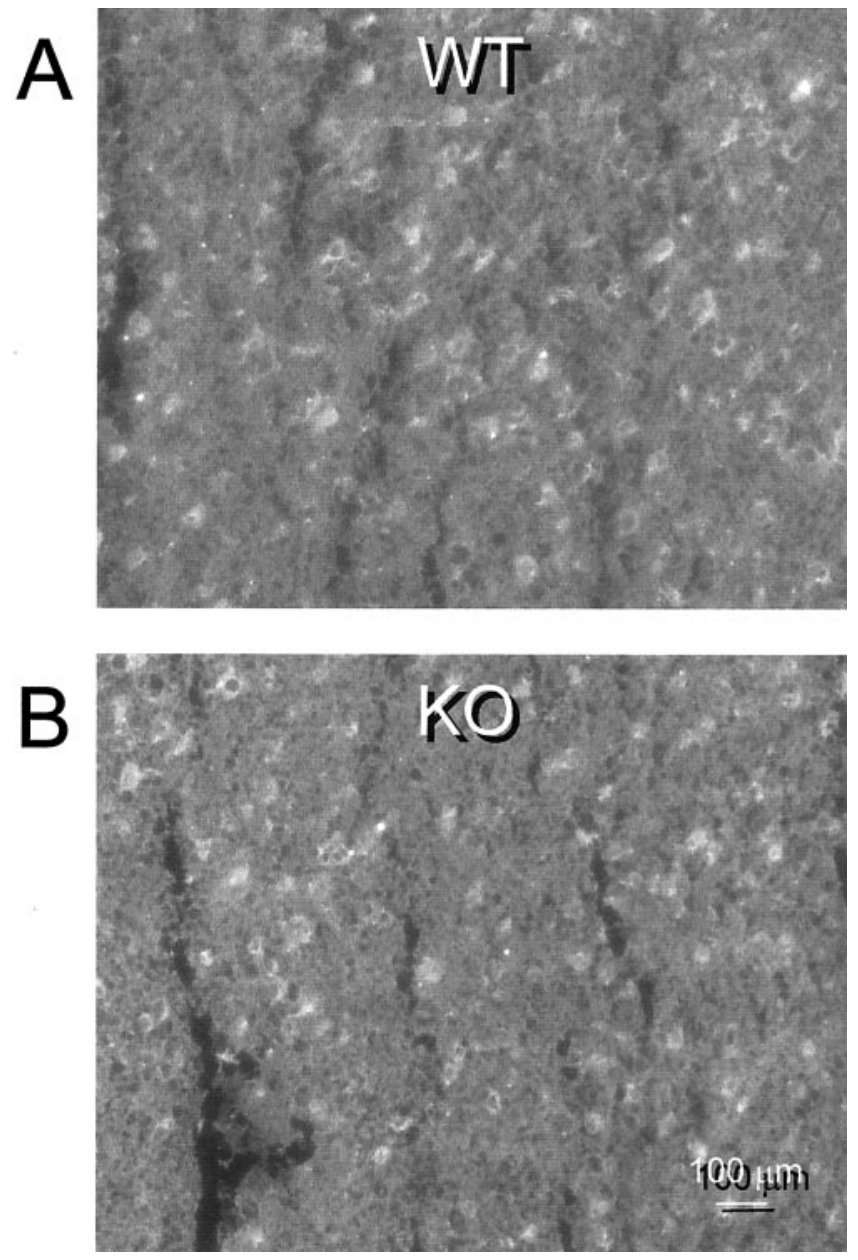

Figure 11. Cellular expression of the $\mathrm{D}_{2}$ receptor in wild-type or NFM-deficient mice is shown in the frontal cortex. The pial surface is toward the top edge in each image. Scale bar applies to both photomicrographs. $A, \mathrm{D}_{2}$ receptor expression is visible within the somata of pyramidal and nonpyramidal neurons of the wild-type (WT) mouse. The neuropil exhibits some reaction for the receptor, corresponding to distribution of the protein along processes and at synaptic structures. $B, \mathrm{D}_{2}$ receptor staining in the NF-M knock-out $(K O)$ mouse appears equivalent to the WT expression pattern. This experiment was performed in two sets of wildtype and knock-out animals with similar results.

determined does not interact with NF-M. There were no qualitative or quantitative differences in the expression of the $\mathrm{D}_{2}$ receptor in the NF-M-deficient mouse compared with wild-type tissue (Fig. 11).

\section{DISCUSSION}

In this study, we have identified NF-M as an interacting protein for the rat $\mathrm{D}_{1}$ dopamine receptor. NF-M was shown to directly interact with the third cytoplasmic loop of this receptor, and yeast two-hybrid analyses were used to demonstrate the specificity of this association. No interaction was observed between NF-M and the third cytoplasmic loops of the $\mathrm{D}_{2}$ subfamily of dopamine receptors, whereas a weak association was detected with the third cytoplasmic loop of the $\mathrm{D}_{5}$ receptor. The third cytoplasmic loop of the $D_{1}$ receptor is known to be important for $G_{s}$-protein activation (Kozell et al., 1994), thus suggesting that NF-M may affect $\mathrm{D}_{1}$ receptor coupling among other functions (see below). The partial-length NF-M cDNA that was originally isolated encoded the $\mathrm{C}$-terminal 65 amino acids of this protein. Hitherto, no function has been ascribed to this area of NF-M, although it is known to be highly acidic (Lee and Cleveland, 1996). Interestingly, there are multiple, positively charged residues within the third cytoplasmic loop of the $\mathrm{D}_{1}$ receptor, suggesting a possible means of association. Future mutagenesis experiments using both NF-M and the $D_{1}$ receptor will be required to delineate the exact residues required for their interaction.

Coexpression of the full-length NF-M and $\mathrm{D}_{1}$ receptor proteins also demonstrated functional interactions confirming the yeast two-hybrid data and in vitro binding assays using the protein fragments. The effect of overexpressing NF-M was a reduction in $\mathrm{D}_{1}$ receptor binding activity in the HEK293 cell membranes. Specificity for this effect was observed in that overexpression of NF-M had no effect on other dopamine receptor subtypes (or minimal effect on the $\mathrm{D}_{5}$ receptor). Confocal fluorescence microscopy, using a $\mathrm{D}_{1}$ receptor-GFP chimera, revealed that NF-M overexpression promoted an accumulation of receptor in intracellular compartments. This may explain the reduced cell surface-plasma membrane expression of the $D_{1}$ receptor observed in the presence of NF-M. It is not clear whether NF-M retards receptor trafficking to the cell surface, perhaps by associating with newly synthesized receptor, or whether the presence of NF-M promotes enhanced or constitutive internalization of the receptor once it is expressed at the cell surface. Further experimentation will be required to distinguish between these possibilities. It should be noted that the effects of NF-M on $D_{1}$ receptor expression in neurons in vivo might be quite different from those observed from overexpression in fibroblast-like cells. The existence of subcellular structures such as neurites and postsynaptic densities, to which NF-M may target $\mathrm{D}_{1}$ receptor expression (see below), provides a level of complexity not easily mimicked in cell culture.

Overexpression of NF-M also reduced the maximal stimulation of $\mathrm{D}_{1}$ receptor-mediated cAMP accumulation. This could be a direct result of reduced receptor expression in the plasma membrane; however, other possibilities cannot be ruled out. For instance, as noted above, the third cytoplasmic loop of the $D_{1}$ receptor is involved in $\mathrm{G}_{\mathrm{s}}$ coupling leading to adenylyl cyclase activation. Overexpression of NF-M might interfere with $G_{s}$ coupling through its association with the third cytoplasmic loop of the receptor and thus attenuate cAMP accumulation. Another possibility is that NF-M may induce constitutive desensitization of the $D_{1}$ receptor. In this case, the receptor would be partially desensitized in the absence of previous agonist activation (Pei et al., 1994). This would be consistent with the above suggestion of constitutive receptor internalization; however, it would not explain why the receptor was not desensitized further with agonist treatment. None of these potential mechanisms for the diminished functional response of the $\mathrm{D}_{1}$ receptor are mutually exclusive.

It was interesting to observe that overexpression of NF-M negated agonist-induced desensitization of the $\mathrm{D}_{1}$ receptor. As noted above, one possible explanation would be that the receptor is already substantially desensitized, although further desensitization after agonist treatment might be expected. Instead, we favor the hypothesis that NF-M association with the receptor may negatively modulate its phosphorylation by protein kinases and/or $\beta$-arrestin association with the phosphorylated receptor protein. This could be attributable to NF-M physically preventing the association of these regulatory proteins with the $\mathrm{D}_{1}$ receptor or by altering the receptor conformation so as to preclude the association with these other proteins. Obviously, the presence and 
level of expression of NF-M has the potential to alter $D_{1}$ receptor signaling. In neurons that coexpress both proteins, $\mathrm{D}_{1}$ receptor activity might be modulated by the close proximity of NF-M in the region of the $D_{1}$ receptor, thus modulating its expression, coupling, or desensitization.

Neurofilament proteins are the major elements of the cytoskeleton in neurons and are abundant throughout the perikarya, axons, and dendrites (Lee and Cleveland, 1996). Neurofilaments are most highly concentrated in large myelinated axons, suggesting a potential role in regulating axonal transport. Thus, NF-M might also be involved in the axonal transport of the $\mathrm{D}_{1}$ receptor to specific presynaptic locations such as the terminals of the striatonigral projection pathway (Huang et al., 1992; Levey et al., 1993; Smiley et al., 1994). Neurofilament expression in dendrites is more diffuse and less organized than in axons; however, neurofilaments have been shown to be associated with postsynaptic densities. This suggests that NF-M may also be involved in targeting the $D_{1}$ receptor to specific subcellular neuronal locations such as dendritic spines (Smiley et al., 1994; Bergson et al., 1995) and other postsynaptic locations. These functions are difficult to demonstrate using transfected cells in vitro and require in vivo experimentation for their elucidation.

To begin to address this issue, immunohistochemical analyses were used to determine that the $\mathrm{D}_{1}$ receptor and NF-M were coexpressed in subsets of neurons within the striatum and frontal cortex of adult rat brain, substantiating that the NF-M could interact with the receptor in normal brain. The striatal colocalization is most likely associated with spiny projection neurons, because this neuron population constitutes the majority of somata within the nucleus. An analogous distribution pattern was detected in the cortex, where only a subset of pyramidal neurons expressed both proteins. The $\mathrm{D}_{1}$ receptor staining did not extend into the distal dendrites of labeled cells, probably because of the level of resolution that we used. It is known that the $D_{1}$ receptor is trafficked in both anterograde and retrograde directions to be distributed presynaptically and postsynaptically (Smiley et al., 1994), but this necessitates using an electron microscopic study of the protein. The fact that there was not complete cellular overlap of NF-M and $D_{1}$ receptor staining suggests that NF-M modulation of $\mathrm{D}_{1}$ receptor function must be cell type-specific in the CNS.

To further substantiate in vivo interactions between NF-M and the $D_{1}$ receptor, we examined the cellular staining of the $D_{1}$ receptor in brains from NF-M-deficient mice. $\mathrm{D}_{1}$ receptor expression in the striatum and cortex was decreased in these mice, in terms of both total positive cells and the intensity and distribution of staining. Notably, there appeared to be decreased staining for the $\mathrm{D}_{1}$ receptor in the apical dendrites of the cortical pyramidal neurons. This may indeed suggest that NF-M assists in the targeting of the $D_{1}$ receptor to these neuronal structures. These results further suggest that it will be important to examine the NF-M-deficient mouse for alterations in $\mathrm{D}_{1}$ receptor-mediated behaviors.

Recently, Huganir and colleagues (Ehlers et al., 1998) have used the yeast two-hybrid system to identify another intermediate filament protein, neurofilament-L (NF-L), as an interacting protein for the NR1 NMDA receptor subunit. NF-L was shown to interact with the NR1 subunit in a splice variant-specific manner and was speculated to be involved in anchoring or localizing NMDA receptors in the neuronal plasma membrane, although specific effects on receptor function were not demonstrated. NF-L thus appears to belong to a family of cytoskeletal and scaffolding proteins that are involved in targeting ligand-gated ion channels to synaptic locations (Kim and Huganir, 1999). Our data extend these findings and describe the first direct interaction of a neurofilament protein with a GPCR. Neurofilament-GPCR interactions may be widespread, however, because activation of the angiotensin $\mathrm{AT}_{2}$ receptor downregulates NF-M expression in PC12W cells (Gallinat et al., 1997), and opiate treatments of rats have been shown to increase neurofilament-H phosphorylation in the brain (Jaquet et al., 2001).

Our results indicate that NF-M can be added to a growing list of proteins referred as DRIPs (dopamine receptor interacting proteins) that have been identified through various protein interaction screens. Many of these proteins are structural or cytoskeletal elements. For instance, the actin binding protein filamin A (ABP-280) was found to modulate the cell surface expression of $\mathrm{D}_{2}$ and $\mathrm{D}_{3}$ receptor subtypes (Bermak et al., 2001; Li et al., 2001). Another actin binding protein, spinophilin, has also been shown to directly associate with the $\mathrm{D}_{2}$ dopamine receptor (Smith et al., 1999). Furthermore, a novel protein named DRiP78 has been identified that regulates $D_{1}$ receptor transport from the endoplasmic reticulum (Bermak et al., 2001). Interestingly, overexpression of DRiP78 retards the cell surface expression of the $D_{1}$ receptor. Further elucidation of the specific functions of these and other dopamine receptor interacting proteins will greatly aid our understanding of dopamine receptor signaling and its regulation.

\section{REFERENCES}

Ariano MA, Sibley DR (1994) Dopamine receptor distribution in the rat CNS: elucidation using anti-peptide antisera directed against $\mathrm{D}_{1 \mathrm{~A}}$ and $\mathrm{D}_{3}$ subtypes. Brain Res 649:95-110.

Ariano MA, Wang J, Noblett KL, Larson ER, Sibley DR (1997a) Cellular distribution of the rat $\mathrm{D}_{1 \mathrm{~B}}$ receptor in CNS using anti-receptor antisera. Brain Res 746:141-150.

Ariano MA, Wang J, Noblett KL, Larson ER, Sibley DR (1997b) Cellular distribution of the rat $\mathrm{D}_{4}$ dopamine receptor protein in the CNS using anti-receptor antisera. Brain Res 752:26-34.

Bergson C, Mrzljak L, Smiley JF, Pappy M, Levenson R, Goldman-Rakic PS (1995) Regional, cellular and subcellular variations in the distribution of $\mathrm{D}_{1}$ and $\mathrm{D}_{5}$ dopamine receptors in primate brain. J Neurosci 15:7821-7836.

Bermak JC, Li M, Bullock C, Zhou Q-Y (2001) Regulation of transport of the dopamine $D_{1}$ receptor by a new membrane-associated ER protein. Nat Cell Biol 3:492-498.

Dong H, Zhang P, Song I, Petralia RS, Liao D, Huganir RL (1999) Characterization of the glutamate receptor interacting proteins GRIP1 and GRIP2. J Neurosci 19:6930-6941.

Ehlers MD, Fung ET, O’Brien RJ, Huganir RL (1998) Splice variantspecific interaction of the NMDA receptor subunit NR1 with neuronal intermediate filaments. J Neurosci 18:720-730.

Elder GA, Friedrich VL, Bosco P, Kang C, Gourov A, Tu PH, Lee VMY, Lazzarini RA (1998a) Absence of the mid-sized neurofilament subunit decreases axonal calibers, levels of light neurofilament (NF-L), and neurofilament content. J Cell Biol 141:727-739.

Elder GA, Friedrich VL, Margita A, Lazzarini RA (1998b) Age related atrophy of motor neurons deficient in the mid-sized neurofilamnet subunit. J Cell Biol 146:181-192.

Gallinat S, Csikos T, Meffert S, Herdegen T, Stoll M, Unger T (1997) The angiotensin $\mathrm{AT}_{2}$ receptor down regulates neurofilament $\mathrm{M}$ in PC12W cells. Neurosci Lett 227:29-32.

Gardner B, Liu ZF, Jiang D, Sibley DR (2001) The role of phosphorylation/dephosphorylation in agonist-induced desensitization of $\mathrm{D}_{1}$ dopamine receptor function: evidence for a novel pathway for receptor de-phosphorylation. Mol Pharmacol 59:310-321.

Huang Q, Zhou D, Chase K, Gusella JF, Aronin N (1992) Immunohistochemical localization of the $\mathrm{D}_{1}$ dopamine receptor in rat brain reveals its axonal transport, pre- and postsynaptic localization, and prevalence in the basal ganglia, limbic system, and thalamic reticular nucleus. Proc Natl Acad Sci USA 89:11988-11992.

Jaquet PE, Ferrer-Alcon M, Ventayol P, Guimon J, Garcia-Sevilla JA (2001) Acute and chronic effects of morphine and naloxone on the phosphorylation of neurofilament-H proteins in the rat brain. Neurosci Lett 304:37-40.

Kim JH, Huganir RL (1999) Organization and regulation of proteins at synapses. Curr Opin Cell Biol 11:248-254. 
Kozell LB, Machida CA, Neve RL, Neve KA (1994) Chimeric $D_{1} / D_{2}$ dopamine receptors. J Biol Chem 269:30299-30306.

Lee MK, Cleveland DW (1996) Neuronal intermediate filaments. Annu Rev Neurosci 19:187-217.

Levey AI, Hersch SM, Rye DB, Sunahara RK, Niznik HB, Kitt CA, Price DL, Maggio R, Brann MR, Ciliax BJ (1993) Localization of $D_{1}$ and $\mathrm{D}_{2}$ dopamine receptors in brain with subtype-specific antibodies. Proc Natl Acad Sci USA 90:8861-8865.

Levine MS, Altemus KL, Cepeda C, Cromwell HC, Crawford C Ariano MA, Drago J, Sibley DR, Westphal H (1996) Modulatory actions of dopamine on $N$-methyl-D-aspartate receptor-mediated responses are altered in $D_{1}$-deficient mice. J Neurosci 16:5870-5882.

Li M, Bermak JC, Wang ZW, Zhou QY (2000) Modulation of dopamine $\mathrm{D}_{2}$ receptor signalling by actin-binding protein (ABP-280). Mol Pharmacol 57:446-452.

Lin R, Karpa K, Kabbani N, Goldman-Rakic P, Levenson R (2001) Dopamine $\mathrm{D}_{2}$ and $\mathrm{D}_{3}$ receptors are linked to the actin cytoskeleton via interaction with filamin A. Proc Natl Acad Sci USA 98:5258-5263.

McVittie LD, Ariano MA, Sibley DR (1991) Characterization of antipeptide antibodies for the localization of $\mathrm{D}_{2}$ dopamine receptors in rat striatum. Proc Natl Acad Sci USA 88:1441-1445.

Muly III EC, Szigeti K, Goldman-Rakic PS (1998) $\mathrm{D}_{1}$ receptor in interneurons of Macaque prefrontal cortex: distribution and subcellular localization. J Neurosci 18:10553-10565.

Neve KA, Neve RL (1997) The dopamine receptors. Totowa, NJ: Humana

Ng GYK, Mouillac B, George SR, Caron M, Dennis M, Bouvier M, O'Dowd BF (1994) Desensitization, phosphorylation and palmitoylation of the human dopamine $\mathrm{D}_{1}$ receptor. Eur J Pharmacol 267:7-19.
O'Brien RJ, Lau LF, Huganir RL (1998) Molecular mechanisms of glutamate receptor clustering at excitatory synapses. Curr Opin Neurobiol 8:364-369.

Pei G, Samama P, Lohse M, Wang M, Codina J, Lefkowitz RJ (1994) A constitutively active mutant $\beta_{2}$-adrenergic receptor is constitutively desensitized and phosphorylated. Proc Natl Acad Sci USA 91:2699-2702.

Sibley DR, Neve KA(1997) Regulation of dopamine receptor function and expression in the dopamine receptors (Neve KA, Neve RL, eds), pp 383-424. Totowa, NJ: Humana.

Smiley JF, Levey AI, Ciliax BJ, Goldman-Rakic PS (1994) $\mathrm{D}_{1}$ dopamine receptor immunoreactivity in human and monkey cerebral cortex: predominant and extrasynaptic localization in dendritic spines. Proc Natl Acad Sci USA 91:5720-5724.

Smith FD, Oxford GS, Milgram SL (1999) Association of the $\mathrm{D}_{2}$ dopamine receptor third cytoplasmic loop with spinophilin, a protein phosphatase-1-interacting protein. J Biol Chem 274:19894-19900.

Tiberi M, Nash SR, Bertrand L, Lefkowitz RJ, Caron MG (1996) Differential regulation of the dopamine $\mathrm{D}_{1 \mathrm{~A}}$ receptor responsiveness by various $G$ protein-coupled receptor kinases. J Biol Chem 271: $3771-3778$

Xia J, Zhang X, Staudinger J, Huganir RL (1999) Clustering of AMPA receptors by the synaptic PDZ domain-containing protein PICK1. Neuron 22:179-187.

Zhang J, Barak LS, Anborgh PH, Laporte S, Caron MG, Ferguson SSG (1999) Cellular trafficking of $G$ protein-coupled receptor/ $\beta$-arrestin endocytic complexes. J Biol Chem 274:10999-11066. 